\author{
EVELYN BROWN
}

When it was announced at the annual representative meeting in Dundee in June that I would be retiring from Family Doctor on health grounds in September, the editor of the $B M F$ asked me if I would like to write something of my experiences, first as assistant editor and later as executive editor of the BMA's health education unit.

In the event, I almost didn't get the job. My interview with Dr Harvey Flack, founder editor of Family Doctor magazine, was for $4 \mathrm{pm}$ on Wednesday 3 October 1956. This is not a date that will have any significance for most people but, as it happened, it was the opening night of the Bolshoi Ballet's first visit to Covent Garden, and I had tickets for Romeo and fuliet starring the great Ulanova.

Those who remember Harvey do so with much affection, but they will also recall what a great talker he was-naturally, as he was half southern and half Ulster Irish. So the interview proceeded and he and I talked about Family Doctor, the BMA, and everything under the sun. It was fairly obvious to me that he was going to offer me the job but at $7 \mathrm{pm}$ (the ballet started at 730 ) I was forced to ask if he would mind very much if I could now be excused. Later, when we got to know each other a lot better he admitted that he'd almost changed his mind about me at that point in case I was "a clock watcher."

I soon realised his anxiety on that point. Being assistant $n$ ditor to Harvey meant working most evenings until 730 a d ev ry Wednesday, when we had our weekly session with our frwance art editor, Alan Morgan, until 9 or even $10 \mathrm{pm}$ if there were special problems ahead of press day. It was very hard work, but also enormous fun.

I insisted that Friday evenings were to be my own (spent usually at Covent Garden or the theatre) but even then there was always a briefcase full of work to be done at home over the weekend.

\section{Early days}

In those days there was the monthly issue of Family Doctor magazine, with at least four give-away promotional booklets included each year. There was also Getting Married and You and Your Baby in two editions published annually, and the beginning of the Fainily Doctor booklet series. We shared the same suite of offices in entrance A of BMA House as the BMF's staff-who, on Dr Hugh Clegg's orders, were forbidden to speak to us, as he and Harvey were conducting a long private feud. Needless to say, we all ignored it except on public occasions.

It would be quite impossible to give any sort of complete history of the ups and downs of the Family Doctor fortunes over the years, so I will stick to some of the events that have remained freshly in my mind.

The magazine was launched in April 1951 in the teeth of hostility from the profession, many of whom felt that the less the public knew about medicine the better. But Harvey was a man with a mission and believed passionately that the health of the nation could be improved enormously by education and persuasion to adopt a different lifestyle. He also felt that the public was avid for medical information presented in language that it

London N2

EVELYN BROWN, former executive editor, BMA health education unit could understand and that if the BMA wouldn't fill this need, then the door was wide open for the quack magazines and the half baked medical columins in the women's magazines that abounded at that time.

The publications were indeed hugely appreciated by the public, who came to trust the advice given. It also quickly put a lot of the more disreputable magazines out of business, and the women's magazines soon followed Family Doctor's lead by taking on qualified doctors to write their medical columns.

With some notable exceptions, the profession still remained deeply suspicious and cautious. The BMA too was unhappy that the unit was still financially shaky.

Our subject matter ranged widely from explanations of medical conditions, with "personal experience" back up pieces from readers, to preventive medicine (we launched the first ever antismoking campaign), baby care and management, and the famous "Family Doctor Answers," one of the most popular sections of the magazine. Questions were sent in by the public and answered by top specialists and experts in the field. All of this was turned into a popular family magazine with the addition of humorous articles, first class photography, cookery, a knitting pattern, and a monthly competition. One of our ventures, to discover the oldest age for a successful full term pregnancy, succeeded in getting our findings into the Guinness Book of Records. Mrs Winifred Wilson of Eccles gave birth to her 10th child, Shirley, when she was aged 54 years and 3 days. This was quickly capped by Mrs Ruth Kistler of Oregon, who had produced her daughter Susan when she was aged 57 years and 129 days.

Some subjects, however, were taboo. In 1957, for example, we failed to persuade the Family Doctor committee to allow us to refer to contraception in any of the publications, but apart from this we were given a free rein.

In 1958 we published our first really large scale experiment by printing 3000000 copies of a book on nutrition, complete with recipes, which was sold in grocers for one shilling. We still get requests for replacement copies today. Things at last seemed to be on the up and up.

\section{Uproar}

The next year was quite a different story. In March we published the fourth edition of Getting Married. It would seem very tame today, but in 1959 it was heady stuff. One article was called "Marrying with a baby on the way" and the other, which caused the maximum uproar, was "Is chastity outmoded ?" by Dr Eustace Chesser. Unfortunately there was very little national news that weekend and the Sunday papers had a field day. They were not concerned that after putting the pros and cons, Dr Chesser had come down on the side of chastity. Front page headlines screamed

\section{BMA CONDONES SEX OUTSIDE MARRIAGE}

\section{DOCTORS IN ROW OVER MARRIAGE BOOKLET}

and so on. There was, in fact, no hullabaloo at this stage as few people had seen it-but by Monday the storm began in earnest. Though most of the doctors had read only the Sunday paper versions, letters of protest and threats of resignation streamed into BMA House. Even the Archbishop of Canterbury requested two copies immediately. 
By Wednesday the news story was beginning to blow itself out. Fate, however, was against us. A high level meeting of BMA officials, against Harvey's advice, decided to issue a "private and confidential" memo to all BMA divisions stating that until the matter had been debated by council no further copies of the booklet were to be issued. The evening papers sniffed out the story the same day. On Thursday the press interest was unbounded.

\section{BMA BANS SEX BOOK}

replaced the earlier headlines. Copies of this one shilling publication began to change hands for $£ 2$ in the Charing Cross Road. Other BMA members threatened to resign if the ban was not lifted. The ARM in Edinburgh later that year narrowly supported the decision to withdraw the booklet, and the entire stock was ceremonially pulped. We were chastened, but unbowed, and I like to think that though we were ahead of our time this publication opened up the frank and honest discussion of sexual matters which we take for granted today.

In 1960 the Family Doctor committee referred to council a request from the Family Planning Association to place a discreet advertisement in Getting Married. Such was the interest in what now would seem commonplace, that a leak from the council agenda appeared in the Daily Express. This in turn provoked a leader in The Times and expressions of horror from numerous sources. As a result it took longer to get a council decision but finally the advertisement appeared two years later in the 1962 version of Getting Married. When in 1969 we published a complete booklet on contraception, it aroused no comment at all.

\section{Health education}

In 1964 we printed 14 million copies of a 64 page booklet called Doctors' Orders and distributed them free to every household in Britain. The editorial content, in suitably simple language, gave medical advice on common ailments, on sleep, tooth care, hygiene and nutrition, complete with recipes. This was undoubtedly the biggest exercise in health education ever undertaken and the project was financed by advertising revenue. The public loved the booklet and we had many requests for extra copies. The profession on the whole hated it. They objected to the advertisements and felt that the booklet "lacked dignity," and so we had another major row on our hands. This time council supported us and though there were a number of critical motions on the ARM agenda, so did the representative body. It was suggested, however, that it would be unwise to repeat the experiment.

In 1966, after a long illness fought with characteristic courage, Harvey Flack died at the early age of 53. Radio and television announcements described him as the best known and most loved family doctor in the country and The Times obituary as "one of the outstanding medical commentators of the day."

It was a doubly shattering blow to all of us at Family Doctor. No suitable successor could be found and the magazine ceased publication early in 1967. It was decided to cut the staff to the minimum and to concentrate on the booklets sold at the chemists and the "giveaways"-namely, You and Your Baby (distributed free to over $90 \%$ of all pregnant women in the UK) and Getting Married. 


\section{Difficult years}

The next few years were difficult ones, with many changes of staff and disagreements about policy and management. Over all hung the constant criticism that the Family Doctor publications group was failing to earn its keep.

The lowest level was reached in 1971 and closure seemed imminent. It was at this point that my colleague Ken Goldsmith and I approached the Family Doctor committee and asked to be allowed the chance to take over, and we became business manager and executive editor, respectively, in 1972. Each year since then has seen an improvement in our position. We increased our publishing activities, paid off fully the outstanding debts, including the launching costs of Family Doctor magazine, and now exist on our own earnings, at no cost to the BMA.

I am glad that we have had no major problems and no public rows in these past 12 years. I am not a combative personality and prefer to get quietly on with the job in hand-giving the public sound information and advice on health matters, and persuading and helping doctors first to write it, and then in many cases to rewrite it for them, to make it suitable for lay readers.

The biggest crisis I had to face was in 1978. I had accompanied the chairman of council (Sir James Cameron) and the secretary of the association (Dr Elston Grey-Turner) to Paris for the launch there of a French version of You and Your Baby. It was a grand occasion and we were honoured by the presence of Madame Simone Weil, at that time the French Minister of Health, at our reception, and all the top officials of the French Medical Association. The BMA party decided to stay on in Paris over the weekend, but I flew back early on Saturday morning as I had tickets that evening for Götterdämmerung at Covent Garden. (Things don't change much, do they ?) On Sunday evening I watched the television news showing a warehouse at St Pancras still burning after the biggest fire since the blitz. Götterdämmerung indeed-for it was the Family Doctor warehouse, no less, and we lost every single publication we possessed, and most of our records.

Phoenix-like we rose from the flames and we were back in business in two months with everything we wished to keep going revised, reprinted, and replaced within a year, thanks to the splendid cooperation of our printers, and all out efforts from the staff.

Earlier this year I had lunch with my old friend Dr Doris Odlum, president of the Samaritans and at the age of 93 still going strong. I told her that I had been advised to take early retirement as soon as possible. "How long have you been at Familv Doctor?" She asked. "Twenty seven years." I said. "Well Brownie, don't have any regrets, you've had a very good innings." Dear Doris. I rest your case.

\title{
Ancylostoma duodenale and the Saint Gothard anaemia
}

\author{
R PEDUZZI，J C PIFFARETTI
}

This year sees the celebration of the centenary of the official opening of the Saint Gothard railway tunnel, and we felt that it would be of interest to recall the epidemic of ancylostomiasis to which so many of the workmen fell victim. This problem of hygiene rightly had wide scientific and political repercussions at the time, as well as echoes among the public. The anaemia, which first appeared in 1880 when the tunnel was being bored, led to major advances in parasitology, by way of research into the aetiology, epidemiology, and treatment of ancylostomiasis. Even to this day, this infestation, which has claimed innumerable victims in tunnels and mines, is still a serious medical and social problem in several tropical countries.

\section{Background}

At the beginning of 1880 a large number of workmen, mostly from Piedmont, returned home because they had severe anaemia, which had rendered them unable to work. Nevertheless, their condition did not improve but became worse, and several workers died. In February 1880 an Italian workman who had been employed in boring the Saint Gothard tunnel died of "pernicious anaemia" in hospital in Turin. During the necropsy Professor Perroncito found no fewer than 1500 ancylostomas in the duodenum and jejunum. ${ }^{2}$ Less than a year later together

Istituto Cantonale Batteriosierologico, 6904 Lugano, Switzerland RAFFAELE PEDUZZI, PHD, director, lecturer at the University of Geneva, Switzerland

JEAN CLAUDE PIFFARETTI, PHD, associate director, lecturer at the University of Geneva, Switzerland with Concato he reported, first to the Academy of Medicine at Turin $^{3}$ and then to the Academy of Sciences in Paris, ${ }^{4}$ three further cases of workers on the Saint Gothard tunnel suffering from severe anaemia in whose faeces numerous ancylostoma ova had been found. The three workers stated that hundreds of their workmates at the tunnel workings had had symptoms similar to their own for a long time.

Two Turin doctors, Bozzolo and Pagliani, then went to Airolo and confirmed the presence of parasite ova in the faeces of numbers of workmen working in the tunnel. Nevertheless, they had strong reservations about the aetiological association between this parasitic infestation and what they called an "epidemic pernicious olighaemia," a disease which, as $\mathrm{Dr}$ Caglioni said about Airolo, resulted in "meeting these sad yellow faces everywhere in the streets of Airolo, faces which were upsetting to see." 5 The roots of the disease, the two doctors thought, were rather to be found in the deplorable conditions of general hygiene, both in the workers' private lives and at their place of work. The alarm about the mysterious Saint Gothard disease was sounded by certain Italian newspapers, with considerable repercussions on public opinion. Motions were submitted to the Italian parliament, which found itself faced with the serious political problem of guaranteeing acceptable living conditions for the thousands of Italian workers employed on the Saint Gothard tunnel.

\section{The controversy}

On 18 March 1880 the Federal Council commissioned Dr Sonderegger to carry out an investigation. After visiting the site, he at first concluded that the Saint Gothard disease was nothing other than a form of the well known "miners' disease," 